\title{
Lower COVID-19 mortality in Italian forested areas suggests immunoprotection by Mediterranean plants
}

\author{
Valentina Roviello ${ }^{1}$ D . Giovanni N. Roviello ${ }^{2}$ D
}

Received: 19 June 2020 / Accepted: 28 July 2020 / Published online: 14 August 2020

(c) Springer Nature Switzerland AG 2020

\begin{abstract}
The COVID-19 pandemic has induced dramatic effects on the population of the industrialized north of Italy, whereas it has not heavily affected inhabitants of the southern regions. This might be explained in part by human exposure to high levels of fine particulate matter (PM) in the air of northern Italy, thus exacerbating the mortality. Since trees mitigate air pollution by intercepting PM onto plant surfaces and bolster the human immune system by emitting bioactive volatile organic compounds (VOCs), we hypothesize a protective role of evergreen forested areas in southern Italy. We compared the mortality rate due to COVID-19, the death number, the positivity rate and the forest coverage per capita in various Italian regions. Hectares of forest per capita and prevalence of deciduous versus evergreen forestal species were also estimated. In silico docking studies of potentially protective compounds found in Laurus nobilis L., a typical Mediterranean plant, were performed to search for potential antivirals. We found that the pandemic's severity was generally lower in southern regions, especially those with more than 0.3 hectares of forest per capita. The lowest mortality rates were found in southern Italy, mainly in regions like Molise $(0.007 \%)$ and Basilicata $(0.005 \%)$ where the forest per capita ratio is higher than $0.5 \mathrm{Ha} /$ person. Our findings suggest that evergreen Mediterranean forests and shrubland plants could have protected the southern population by emission of immunomodulating VOCs and provision of dietary sources of bioactive compounds. Moreover, in silico studies revealed a potential anti-COVID-19 activity in laurusides, which are unexplored glycosides from bay laurel. Overall, our results highlight the importance of nature conservation and applications to the search for natural antivirals.
\end{abstract}

Keywords SARS-CoV-2 $\cdot$ COVID-19 $\cdot$ Air pollution $\cdot$ Particulate matter $\cdot$ Forest bathing $\cdot$ Mediterranean vegetation . Laurus nobilis $\cdot$ Plant therapeutics $\cdot$ Plant toxicity $\cdot \mathrm{M}^{\text {pro }}$ inhibitors

\section{Introduction}

COVID-19 (COronaVIrus Disease 19) is a novel disease characterized in several cases by severe pneumonia, caused by severe acute respiratory syndrome coronavirus 2 (SARSCoV-2) previously indicated as 2019-new coronavirus (2019-nCoV). COVID-19 emerged in Wuhan, central China,

Electronic supplementary material The online version of this article (https://doi.org/10.1007/s10311-020-01063-0) contains supplementary material, which is available to authorized users.

Giovanni N. Roviello

giroviel@unina.it; giovanni.roviello@cnr.it

1 Department of Chemical, Materials and Industrial Production Engineering (DICMaPI), University of Naples Federico II, Piazzale V. Tecchio 80, 80125 Naples, Italy

2 Istituto Di Biostrutture E Bioimmagini IBB - CNR, Via Mezzocannone 16, 80134 Naples, Italy in December 2019 (Lai et al. 2020; Wu et al. 2020). However, COVID-19 has spread rapidly worldwide, becoming a global issue with several countries all over the world reporting numerous cases of infection (Hunter 2020). This led the world health organization (WHO) to declare it a pandemic on 11 March 2020 (Sinonquel et al. 2020).

SARS-CoV-2 is a betacoronavirus closely related to other bat-derived severe acute respiratory syndrome (SARS)like coronaviruses ( $\mathrm{Lu}$ et al. 2020; Park et al. 2020), and it is a subject of several research studies in environmental chemistry in the attempt to understand its behaviour in the environment (Sharma et al. 2020). This virus is also related to the SARS-CoV-1, sharing about $79 \%$ genomic identity, which caused SARS in 2002-2003 (Anderson et al. 2004), a coronaviral epidemic which led to deaths mainly in Asia (Anderson et al. 2004).

Recently, the ESA (European Space Agency) and NASA (U.S. National Aeronautics and Space Administration) 
released data showing that pollution in the main epicentres of COVID-19 such as China, a country heavily affected by air pollution (Feng and Zheng 2019), Italy, Spain and the USA, has reduced significantly, up to $30 \%$ (Muhammad et al. 2020), even though an unexpected rise of ozone air pollution (Yu 2018) was observed in both urban and rural areas (Wang et al. 2020). On the other hand, several studies showed that air pollution is a risk factor for acute respiratory infection by affecting the body's immune system and by carrying microorganisms (Cai et al. 2007; Susanne Becker 1999; Sun et al. 2016; Xie et al. 2019). It was also shown that environmental pollutants are in correlation with the severity of COVID-19 (Bashir et al. 2020; Zhu et al. 2020) and, in particular, particulate matter (PM) (Mukherjee and Agrawal 2017, 2018; Dang and Shan 2017) in combination with humidity significantly increases the risk of COVID-19 incidence (Jiang et al. 2020).

This would suggest that air pollution control can reduce the harmful effects of the global pandemic (Bashir et al. 2020). The air quality effect on the confirmed cases of COVID-19 was stronger in the temperature range of $10-20{ }^{\circ} \mathrm{C}$, while the relative risk of COVID-19 transmission associated with air quality was higher in the $10-20 \%$ relative humidity range, suggesting a higher impact of air quality on the COVID-19 spread under low relative humidity (Xu et al. 2020). Northerly latitude was generally associated with increased mortality and hospitalization rates for COVID-19 worldwide due to several factors such as the deficiency of vitamin $\mathrm{D}$, a vitamin with immuno-modulatory properties, caused by low ultraviolet exposure, as well as low temperature and relative humidity conditions allowing the virus to survive longer outside the human body (Panarese and Shahini 2020).

Interestingly, several Mediterranean countries have experienced a milder impact of the virus, with low morbidity and mortality linked to COVID-19 (Panarese and Shahini 2020). This can be explained by the rigorous control measures taken by the local governments who did not ignore the lessons from northern Italy (Frogoudaki 2020; Saglietto et al. 2020). Nevertheless, in concurrence with the measures put in place, the above-cited effects of latitude, climate, the availability of vitamin D as well as other environmental factors together with the Mediterranean diet could have resulted in the more favourable outcome recorded in the Mediterranean area (Cena and Chieppa 2020).

Italy showed significant regional differences in the impact of COVID-19, with it being more dramatic in the north when compared to the significantly milder situation observed in the south (Signorelli et al. 2020).

Owing to the importance of trees in air pollution mitigation, as emitters of bioactive volatile organic compounds (VOC) and as having beneficial effects in bolstering the body's immune system, we decided to explore the impact of
COVID-19 in the Italian regions in relationship to the abundance of forest cover. Moreover, as an example, we investigated a typical Mediterranean plant, i.e. bay laurel ( $L a u-$ rus nobilis L.) (Alessi et al. 2018), as a source of potential anti-COVID-19 natural products, studied in silico for their abilities to bind $\mathrm{M}^{\text {pro }}$, the main protease of SARS-CoV-2 (Jin et al. 2020). They were also studied for their toxicity with a particular attention paid to laurusides, a scarcely explored class of compounds from laurel that could disclose interesting biological activities (Duc Dat et al. 2019).

\section{Experimental}

\section{Estimation of forest area/inhabitant and other parameters mentioned in this work}

The 2015 forest area data for the Italian regions, released by Italian National Forest Service (INFC), are available in the table reported on page 4 (CREA INFC 2015) of the following link: https://www.politicheagricole.it/flex/cm/pages /ServeAttachment.php/L/IT/D/7\%252Fe\%252Fd\%252FD .fad376b863247ad7355a/P/BLOB\%3AID\%3D14652/E/pdf. To calculate the forest area per capita values of Table S1 (see Results and Discussion) for each region, we divided the number of hectares of forest reported at the link above by the number of inhabitants (reported at the link https:// dati.istat.it/Index.aspx?QueryId=18460\&lang=en). We estimated prevalence of deciduous vs. evergreen forestal species in Aosta Valley, Trentino and South Tyrol regions (Results and Discussion) by using the data furnished by INFC, available at the link: https://www.sian.it/inventarioforestale/caric aDocumento?idAlle $=421$ COVID-19 data for Italian regions were reported at the link https://en.wikipedia.org/wiki/ COVID-19_pandemic_in_Italy (data as of 20 May 2020).

\section{Molecular docking}

The three-dimensional structure of the protein target from SARS-Cov-2, i.e. the main protease $\mathrm{M}^{\text {pro }}$ (PDB ID: 6YB4), was obtained from Protein Data Bank (Berman et al. 2002). The 2D structures for the ligands were retrieved from PubChem database (https://pubchem.ncbi.nlm.nih.gov/), while those not available in PubChem were drawn using the molecular editor provided in 1-Click Mcule (Mcule Inc., Palo Alto, CA, USA) (Potemkin et al. 2019; Fik-Jaskółka et al. 2020a,b, a; Kiss et al. 2012), a web-based platform powered by AutoDock Vina docking algorithm (Trott and Olson 2009) by which we realized our docking experiments. The atomic coordinates of the binding site were those reported in the recent literature (Umesh et al. 2020) ( $X$ : 9.204, $Y:-4.557$ and $Z: 19.602)$, and the size of the binding site was 22 Angstrom. We selected the docking poses with 
Fig. 1 Bar graphs showing the abundance of forest areas (a) as well as some parameters useful to describe the COVID-19 impact on local populations within eight representative regions of Italy. These include the percentage of COVID-19 fatalities/number of inhabitants (b), positivity rates (c) and the number of deaths (d). Note the higher coronavirus impact on regions like Emilia Romagna, Lombardia and Veneto which have less than 0.2 hectares of forest per capita when compared to the significantly more favourable situation within the regions where the above ratio was higher than 0.34 hectares/inhabitant

the most negative docking scores $(\mathrm{kcal} / \mathrm{mol})$ corresponding to the highest binding affinities. We validated the method applying it to other literature dockings targeting $\mathrm{M}^{\text {pro }}$, finding our binding energy scores in line with those previously reported for carnosol (Umesh et al. 2020), apixaban and other ligands docked to the same protein target (Chakraborti et al. 2020). The molecular graphics program incorporated in 1-Clik Mcule was used for structural visualization of protein-ligand interactions and to obtain the snapshot of Fig. 4, while the protein-ligand interaction diagram shown in the same figure was obtained by ProteinsPlus (https:// proteins.plus/) (Rarey et al. 2020).

\section{Potential oral lethal dose toxicity class determination and other toxicity parameters.}

The potential oral lethal dose toxicity class for lauruside 5 and reference compounds was evaluated on the ProTox webbased server (tox.charite.de). The toxicities are classified into six classes (I-VI) (Drwal et al. 2014) and the predicted toxic doses (in rodents) were reported as $\mathrm{LD}_{50}$ values in $\mathrm{mg} /$ $\mathrm{kg}$ body weight. ProTox also suggested the potential toxicity targets for lauruside 5 .

\section{Results and discussion}

\section{COVID-19 impact in Italian regions with different forest cover areas}

Comparing the number of deaths due to COVID-19 with rates of forest area per inhabitants in the different Italian regions (Fig. 1, Table S1), we found there to be generally less deaths in the regions having $\geq 0.34$ hectares of forest/ number of inhabitants.

If one considers the Italian regions which have to date (as of 26th May 2020) less than 300 fatalities related to SARSCoV-2 infection (Table S1), all but Sicily are endowed with almost an acre of forest per capita (Table S1). Normalizing the number of victims by total population, we observed that 5 out of 7 regions with less than $0.01 \%$ COVID-19 deaths/ total population still had at least 0.34 hectares of forest/ number of inhabitants. Peculiar features including proximity
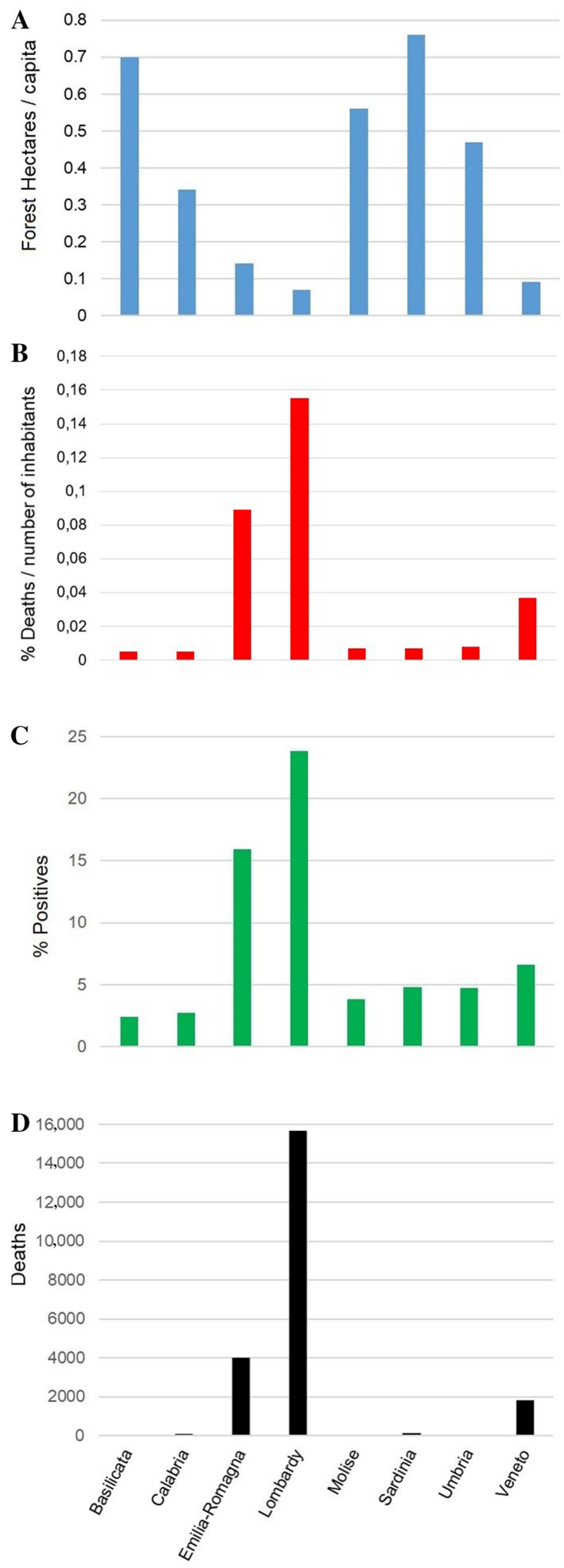
to the coast of the largest cities, particularly mild weather, presence of cultivated areas with Mediterranean orchards and Mediterranean wild shrubland with oleanders (Nerium Oleander L.), holm oaks (Quercus Ilex L.), wild olive trees (Olea europaea L.) or other plants with promising effects on air pollution mitigation (Blanusa et al. 2015; Abed-Esfahani et al. 2013a,b; Kaur and Nagpal 2017), could all account for the favourable outcome of Sicily. This latter, in fact, presents the third lowest percentage of positive COVID-19 tests (3.0\%, Table S1) after Calabria (2.7\%) and Basilicata (2.4\%). Interestingly, the two italian regions with the lowest mortalities due to COVID-19, i.e. Molise and Basilicata, are also situated in southern Italy and have high ratios of hectares of forest/number of inhabitants: 0.56 and 0.70 , respectively (Fig. 1, Table S1). Examining the same aspects for northern Italy, we still found higher forest areas per inhabitant in the regions with lower numbers of deaths due to COVID-19. Remarkably, Lombardy, having the lowest forest area per capita within northern Italy, was not only the region with the highest number of COVID-19 victims ( $>15,000$, Fig. 1 , Table S1), but it also had the highest level of occupancy of intensive care unit beds (Odone et al. 2020) as well as the highest rate of positive tests $(23.8 \%$, Fig. 1, Table S1). Within the northern regions with less than 300 COVID-19 victims, this rate (4.7-17.1\%) was lower than Lombardy, but generally higher than the 'greener' regions of southern Italy (2.4-3.8\%, Table S1). As an example, South Tyrol (520,000 inhabitants, northern Italy) presents a similar forest area per capita $(\sim 0.7 \mathrm{Ha} /$ person) compared to Basilicata $(560,000$ inhabitants, southern Italy), but a $\sim 5$ times higher rate of positive tests (Table S1). This could be associated to several factors including differences in virus abundance, due to obvious different geographic distances from the regions where the pandemic started in Italy (Odone et al. 2020), but which could also include the differences in latitude, climate, proximity to coast and the local diet. Nevertheless, there is the possibility that the Mediterranean vegetation present in the southern regions of the country could be playing a protective role.

When comparing the neighbouring South Tyrol and Trentino, we notice that the former, with forests composed mainly of evergreen trees (see Experimental section) has a significantly lower rate of COVID-19 deaths/total population $(0.053 \%)$ than the latter $(0.084 \%)$ which has a large predominance of winter-dormant deciduous trees (see Experimental section). Interestingly, Aosta Valley, despite its very high ratio of hectares of forest (but with a significant rate of deciduous trees, see Experimental section)/number of inhabitants $(0.89 \mathrm{Ha}$ /person) presents a COVID-19 death rate per total population that is more than 10 times higher than that of Molise $(0.007 \%)$ and Basilicata $(0.005 \%)$. Lockdown measures were undertaken in Aosta Valley at the same time as these two regions. This difference could be tentatively explained on the basis of a combination of factors besides the most obvious, i.e. distance from COVID-19 epicentre and the intense winter tourism fluxes in Aosta Valley from Lombardy: latitude, sunlight/climate and the abundance in southern Italy of Mediterranean plants, both cultivated and spontaneous trees. Remarkably, studying the pandemic in Italy using the basic reproduction number $\mathrm{R}_{0}$, average number of people that can be infected by an already infected person, the four lowest $R_{0}$ values determined by Distante et al. (Distante et al. 2020) were given to the four southern regions with the highest forest cover area per inhabitant.

A hypothesis of association between severity of the current pandemic of COVID-19 and high levels of fine particulate matter (PM) in urban areas, an issue in Lombardy and other areas of northern Italy, was recently brought forth (Conticini et al. 2020). In fact, the particulate matter could play a role in spreading the SARS-CoV-2 virus in the air (Setti et al. 2020) and is also linked to respiratory pathologies in turn responsible for higher COVID-19 mortality rates (Dutheil et al. 2020). Fine PM penetrating into the respiratory system can easily provoke inflammatory responses as well as cardiovascular and pulmonary diseases, thus exacerbating respiratory distress. This seemed particularly evident in northern Italy where COVID-19 disease provoked the highest number of victims in the country, as well as one of the most worrying situations worldwide, and where PM concentrations of $\geq 50 \mu \mathrm{g} / \mathrm{m}^{3}$ as PM10 daily averages were often recorded (Setti et al. 2020).

The beneficial role of trees in removing air pollution is well known and described in the literature (Grzędzicka 2019). In fact, by intercepting the particulate matter on leaves and other plant surfaces, and absorbing gaseous pollutants through their leaf stomata, urban trees are notoriously adept to air purification (Nowak et al. 2014, 2018). In this context, several plants belonging to the class of Mediterranean vegetation, such as the holm oak (Quercus ilex L.), bay laurel (Laurus nobilis L.) and others, were found able to cleanse the atmosphere, trapping among other pollutants several polycyclic aromatic compounds (Sgrigna et al. 2015; Gratani and Varone 2013; Fellet et al. 2016). Owing to the role of urban forests in decreasing concentrations of particulates and other pollutants, thus improving air quality, it was recently argued that they can also contribute to reducing the impact of COVID-19 (Fares et al. 2020).

\section{Mediterranean trees as sources of biogenic volatile organic compounds with immune-modulatory activities}

We have analysed the literature data on the protective role of Mediterranean plants, viewed as unique sources of useful metabolites displaying positive effects against various pathogens (Kahkha et al. 2013), within the context of the 
current pandemic episode. We payed particular attention to the effect on the human immune system triggered by the inhalation of volatile compounds emitted by trees. We found that 'forest bathing', the practice of visiting a forest for its health benefits, has positive effects, especially on the human immune function ( $\mathrm{Li}$ 2009), which last more than one week post-exposure ( $\mathrm{Li}$ et al. 2008). These include the increase in natural killer (NK) activity, mediated by increased NK cell numbers and intracellular granulysin, perforin and granzymes A/B release, with reported effects against tumours and virus-infected cells (Li 2009). We also found several literature reports on the beneficial effects of some plant terpenes on the anti-inflammation response elicited by these volatile organic compounds (VOC) on airway inflammation in animal models (Kim et al. 2020), as well as reports on essential oil components able to reduce pulmonary inflammation induced by air pollution (Kfoury et al. 2016).

Borneol and terpineol have been shown to have antiasthmatic activity, inhibiting in vitro bronchoconstriction in guinea pigs (Kim et al. 2020), whereas a placebo-controlled, double-blind trial revealed the clinical efficacy of 1,8-cineole in inflammatory airway diseases, such as chronic obstructive pulmonary disease and asthma (Worth and Dethlefsen 2012; Juergens 2014). A positive therapeutic effect of bornyl acetate, a volatile compound isolated from twigs, leaves and fruits of several plants including the Mediterranean Laurus nobilis L. (Fidan et al. 2019), has been reported for the treatment of lung inflammation in an animal model of acute lung injury (Chen et al. 2014). Moreover, $\alpha$-pinene was effective for treatment of allergic rhinitis (Nam et al. 2014), while $\beta$-caryophyllene has demonstrated both anti-inflammatory and antinociceptive activity (da Silva et al. 2020; Klauke et al. 2014). Since COVID-19 emerged in Italy during the cold season, we wondered whether the VOC emissions in Mediterranean countries were completely inhibited during fall and winter months. Through literature analysis, we found that even though biogenic VOCs are emitted in larger amounts by plants during spring and summer than during fall and winter, significant amounts of bioactive terpenes can still be detected in Mediterranean ecosystems during winter. This phenomenon has also been observed with betacaryophyllene, whose winter emission from Cistus monspeliensis $\mathrm{L}$. was similar to that found during spring and six times higher than the amount detected during summer (Rivoal et al. 2010).

Mediterranean trees are classified as isoprene, $\alpha$-pinene, linalool and limonene emitters, and the most representative of these is the Mediterranean oak, i.e. Quercus ilex L., also known as holm oak, which is able to release in the air up to 19 VOCs (Owen et al. 2001). More abundant VOCs in Laurus nobilis $\mathrm{L}$ are $\beta$-pinene (19.44\%), 1,8-cineole (19.38\%), $\beta$-caryophyllene $(8.55 \%)$ and sabinene $(7.91 \%)$; however, numerous other volatile compounds are found in lesser amounts in this Mediterranean plant (D'Auria and Racioppi 2015).

\section{Antiviral activity of natural compounds from Mediterranean plants}

Besides the study of plant VOCs with beneficial effects on the immune system, we also focused on several other compounds with therapeutic potential which are contained in vegetal sources. We analysed the literature reports finding that several Mediterranean plants of culinary use, such as Salvia officinalis L., Satureja thymbra L. and Laurus nobilis L., are used as folk remedies in different countries to treat numerous diseases including viral ones (Loizzo et al. 2008). Strikingly, one of the most promising anti-COVID-19 candidates emerged by our literature analysis is Laurus nobilis $\mathrm{L}$. oil, characterized by the presence of $\beta$-ocimene, 1,8 -cineole, $\alpha$-pinene and $\beta$-pinene as its main constituents, which exerted an interesting activity against SARS-CoV-1 with an $I C_{50}$ value of $120 \mu \mathrm{g} / \mathrm{ml}$ and a selectivity index (SI) of 4.16 (Loizzo et al. 2008). Laurus nobilis L. is a typical Mediterranean plant, constituent of Laurisilva forests (Pignatti et al. 2015), commonly used as a flavouring agent for food preparation, but also endowed with many biological activities. These antioxidant and antimicrobial properties are due to the chemical composition of the essential oil found within its leaf which varies depending on the latitude and climate of its cultivation site (Riabov et al. 2020).

For its part, Pistacia vera L. kernels and seeds showed significant activity against Herpes simplex and Parainfluenza viruses in cell experiments (Özçelik et al. 2005). The chemical components of the methanolic extract of Onopordum illyricum L. aerial parts showed significant inhibition activities against human immunodeficiency virus 1 (HIV-1) reverse transcriptase, but also against HIV-1 integrase and blocked viral replication in cell-based assays (Sanna et al. 2018). The ethyl acetate and methanol extracts of Daucus virgatus exhibited significant inhibitory effects against $C o x$ sackievirus $B$, a small RNA virus of the Picornaviridae family (Snene et al. 2017). Worthy of note is the fact that the wood extract from one of the most abundant trees in the Mediterranean forests, Quercus ilex L., showed antiviral effects against (H9N2) influenza and bovine viral diarrhoea (BVD) viruses, this latter being a pestivirus model of hepatitis C virus (HCV), on MDCK cells (Yousef et al. 2014a, b).

In addition, we also explored the published data on the olive tree (Olea europaea L.), a symbol of the Mediterranean world since ancient times, and found that it is used as a folk remedy for the cure of numerous disorders including those of viral origin (Hashmi et al. 2015). This practice has found scientific justification through the demonstrated antiviral activity of olive leaf extracts, safe both for our health 
and the environment, and the effectiveness of its main constituent oleuropein (Micol et al. 2005).

\section{Laurus nobilis against SARS-CoV-2: in silico studies on potential laurel-derived inhibitors of SARS-CoV-2 main protease $\left(\mathrm{M}^{\mathrm{pro}}\right)$ and toxicity prediction}

We decided to investigate laurel components as potential anti-COVID-19 drugs starting from the evaluation in silico of their binding affinity for one of the main viral protein targets. In fact, as reported in the previous section, an in vitro investigation on the biomedical properties of the essential oil taken from Laurus nobilis L. revealed its potential antiviral activity against SARS-CoV-1 (Loizzo et al. 2008). This called our attention to its possible therapeutic use against the genetically close SARS-CoV-2, a hypothesis which has also been brought forth in recent literature (Hensel et al. 2020). The essential oil from the aerial parts of the plant, which contains the monoterpenes 1,8-cineol and $\beta$-ocimene, and the sesquiterpene dehydrocostus lactone in larger amounts than other essential oils, inhibited the replication of SARSCoV-1 in vitro (Loizzo et al. 2008).

Furthermore, we found published reports showing that, besides the terpenic compounds, several other phytochemical constituents were isolated from Laurus nobilis L. including alkaloids, phenolics and megastigmanes (De Marino et al. 2004). Within this latter group, we noticed that the recently identified laurusides 1-7 (Duc Dat et al. 2019) are an almost unexplored class of laurel-derived compounds (Fig. 2).

Among the coronaviral protein targets evaluated in computational studies, $\mathrm{M}^{\text {pro }}$ (also called $3 \mathrm{CL}^{\text {pro }}$ ) protease represents a first choice potential target for the inhibition of SARS-CoV-2 replication. This is a well-characterized protein of SARS-CoV-2 which shares $96 \%$ identity with SARS-CoV-1 $\mathrm{M}^{\text {pro }}$ (Zhang et al. 2020) and has a key role in

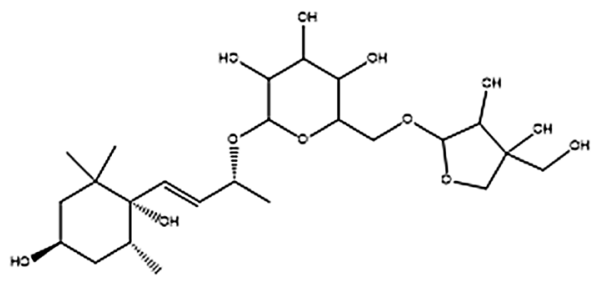

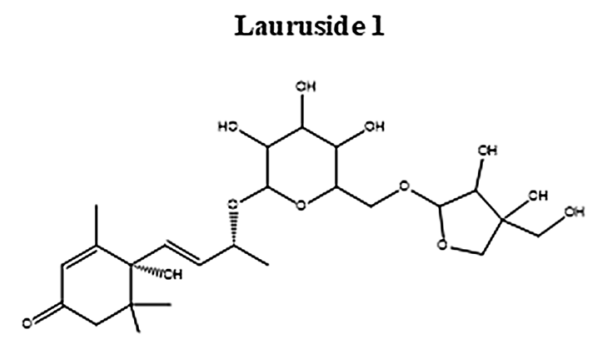

Lauruside 5

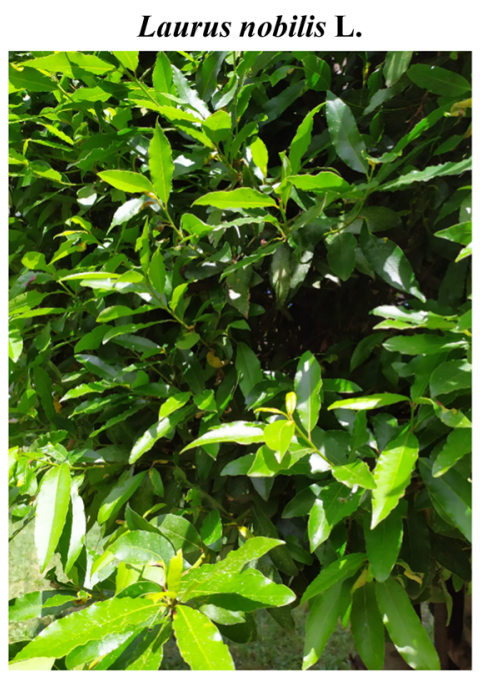

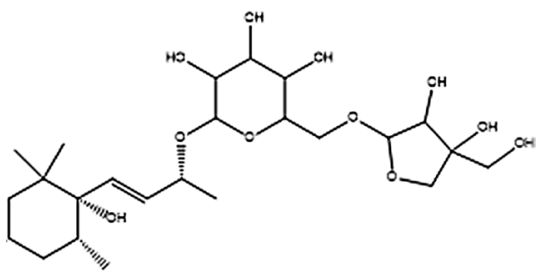

Lauruside 2

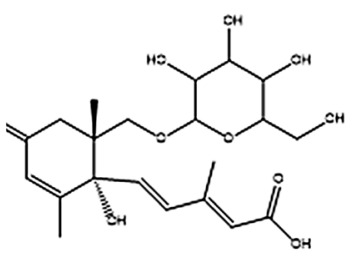

Lauruside 6<smiles>CCC1CC(CC(C)C=C[C@]2(C)C(C)=CC(=O)CC2(C)C)C(O)C(O)C1C</smiles><smiles>C=C1C[C@H]2C(CC[C@]3(C)C=C[C@H](CC(C)=O)C(=C)[C@]23C)C1=C</smiles><smiles>Cc1c(-c2ccc(I)cc2)oc2cc(I)cc(Br)c2c1=O</smiles>

Fig. 2 Laurus nobilis L. plant foliage and molecular structure representation of some of the compounds extracted from laurel with the highest predicted affinity for SARS-CoV-2 main protease $\left(\mathrm{M}^{\mathrm{pro}}\right)$. Of these, Laurusides $1,2,5,6$ and 7 belong to the class of laurel glyco- sides, while $3 \alpha$-acetoxyeudesma-1 4(15) 11(13)-trien-12 6 $\alpha$-olide and Kaempferol are classified as sesquiterpene and flavonoid compounds, respectively. Photograph taken by Dr. V. Roviello in Aversa, South Italy on 21 May 2020 
the coronaviral life cycle. All these aspects, together with the absence of any similar protein homologues in humans, rendered it an attractive target for our anti-COVID-19 drug discovery. One should note that some of the repurposed treatments for COVID-19 (Costanzo et al. 2020) are protease inhibitors such as the lopinavir-ritonavir combination (Mangum and Graham 2001). Based on the importance of $\mathrm{M}^{\text {pro }}$ as a drug target in the fight against SARS-CoV-2, we focused on several phytochemicals derived from the bay laurel for their potential antiviral activity towards the novel coronavirus studied by docking to the main protease $\mathrm{M}^{\text {pro }}$ of SARSCoV-2. By using 1-Click Mcule docking server (Potemkin et al. 2019; Kiss et al. 2012), which makes use of AutoDock Vina software (Trott and Olson 2009), we have analysed 44 laurel-derived compounds. Nine molecules, belonging to three molecular families: laurusides, sesquiterpene lactones and tetrahydroxyflavones, showed high affinity scores towards SARS-CoV-2 $\mathrm{M}^{\text {pro }}$, with $\leq-7.0 \mathrm{kcal} / \mathrm{mol}$ binding energy values for the top ranked poses, as shown in Fig. 3 and Table S2.

Six out of nine of these ligands belong to the family of laurusides described by Duc Dat et al. (Duc Dat et al. 2019), natural products extracted by Laurus nobilis L. able to inhibit, in cell, the lipopolysaccharide (LPS)-induced nitric oxide release.

In particular, lauruside 5 showed in silico the lowest binding energy $(-8.2 \mathrm{kcal} / \mathrm{mol}, \mathrm{BE}$ for the top scoring pose, and $-7.5 \mathrm{kcal} / \mathrm{mol}$, average score; Fig. 3, Table S2) and, thus, the highest affinity for $\mathrm{M}^{\text {pro }}$. Other good affinity scores were found for laurusides 1, 2, 6 and 7, as well as for kaempferol $(-7.4 \mathrm{kcal} / \mathrm{mol}$, score of the top ranked pose). We examined the pose corresponding to the lowest energy

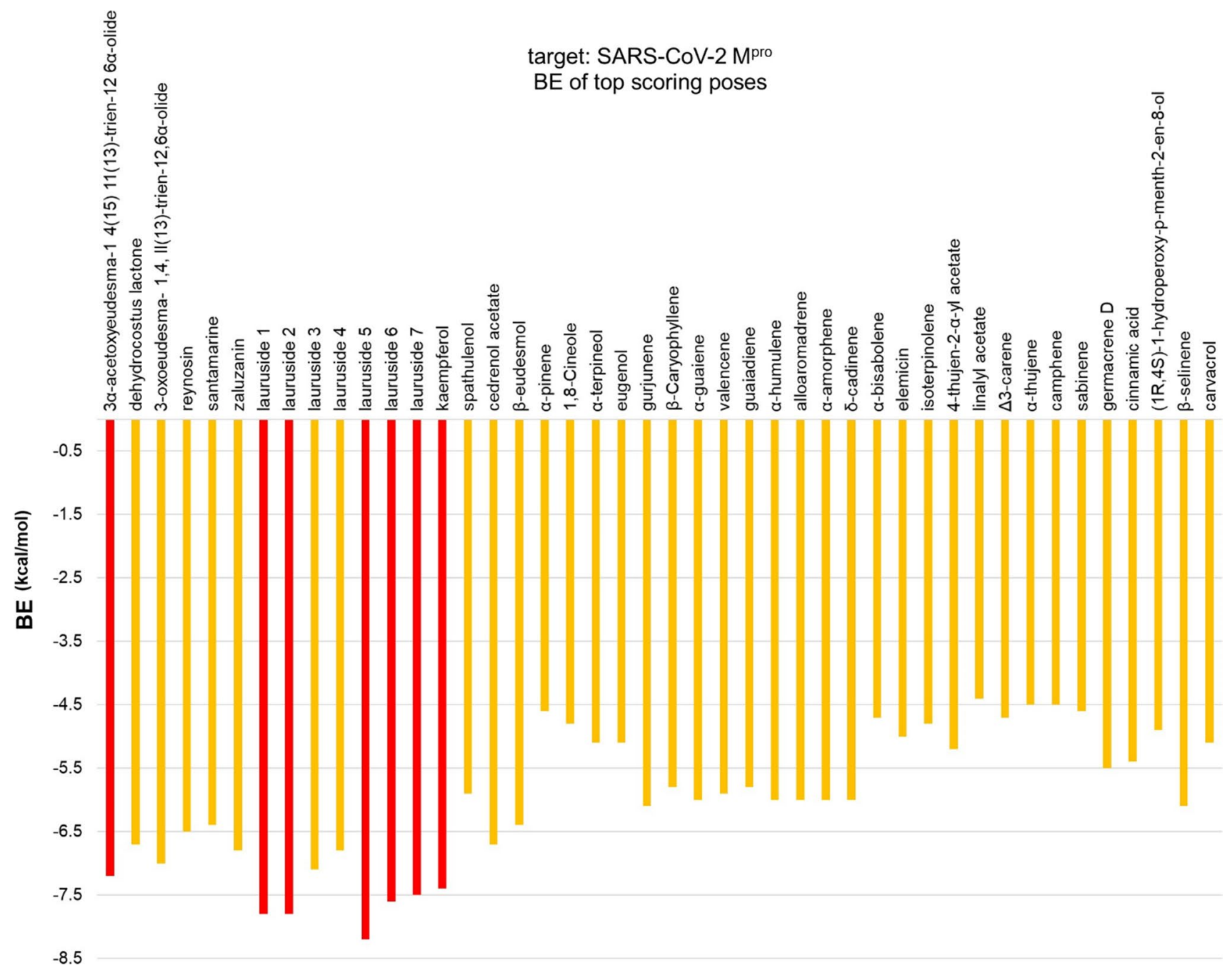

Fig. 3 Bar graph showing the predicted binding energy (BE) scores in $\mathrm{kcal} / \mathrm{mol}$ (as obtained by 1-Click Mcule web-based docking program) for different classes of compounds, such as volatile compounds and glycosides, found in the Laurus nobilis L. plant. Bars indicat- ing the binding energy for the compounds with the highest affinities for the protein target, SARS-CoV-2 main protease (M ${ }^{\text {pro; }}$ PDB ID: $6 \mathrm{YB} 4)$, are evidenced in red 

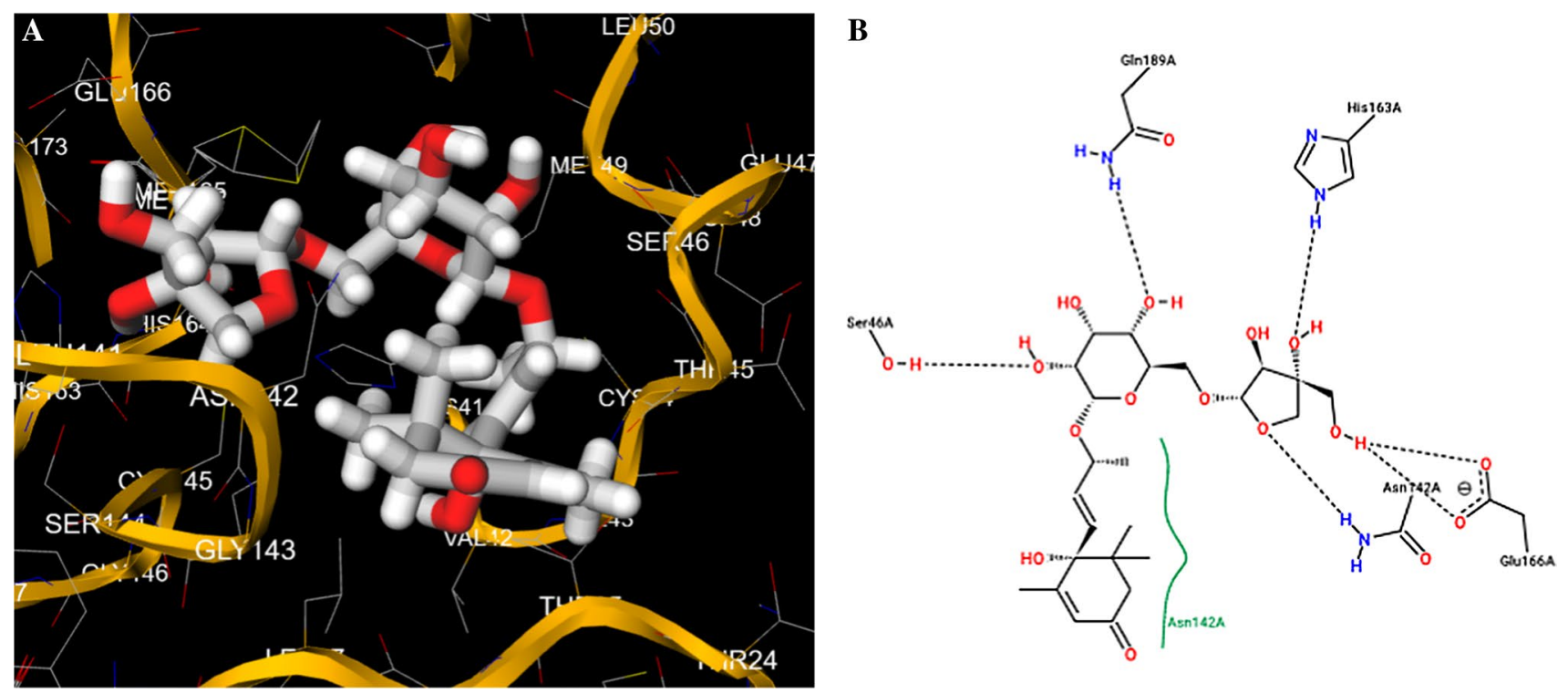

Fig. 4 Putative best docking pose (a) and 2D protein-ligand interaction diagram (b) at the active site of main protease $\mathrm{M}^{\text {pro }}$ for lauruside 5. Proximity of functional groups of the laurel glycoside to Ser46, Asn142, Glu166 protein residues is observed in the pose view (a), while main interactions, including H-bonds with amino acids Ser46,

for lauruside 5 and observed that this glucoside derivative was involved in multiple H-bonding with residues Ser46, Asn142, His163, Glu166 and Gln189 (Fig. 4). These latter interactions were previously reported for the interaction of carnosol to the same protease target (Umesh et al. 2020).

We evaluated in silico the toxicity of the most promising candidates belonging to the lauruside group by using the program ProTox (tox.charite.de) and found, with a prediction accuracy of $\sim 70 \%$, that all of them are assigned to the predicted toxicity class IV (see as an example Fig. S1 for lauruside 5, Table S3), that is the same corresponding to the commonly-used anti-COVID-19 drug hydroxychloroquine (Peytavin et al. 2020) (Fig. S3), with a predicted median oral lethal dose $\left(\mathrm{LD}_{50}\right)$ in rodents for the most promising lauruside 5 of $2500 \mathrm{mg} / \mathrm{kg}$ (Fig. S1). Possible toxicity targets were predicted as Amine Oxidase A and Prostaglandin G/H Synthase 1 (Fig. S2). On the other hand, the predicted toxicity class (class V) of kaempferol (Fig. S3, Table S3) suggests a higher biosafety potential for this tetrahydroxyflavone isolated from Mediterranean plants, even though its affinity for $\mathrm{M}^{\mathrm{pro}}$ is lower than lauruside 5 (Table $\mathrm{S} 2$ ).

Since AutoDock Vina software tends to underestimate the binding affinity of the ligands for the target (Lambert et al. 2019), our complexes could be endowed with an even lower binding energy and thus, with a higher affinity than that theoretically computed. In other terms, our study could serve as a starting point for future experimental investigations directed to characterize the above ligand-protease interactions and the in vitro/in vivo anti-SARS-CoV-2 effects of
Gln189, His163, Asn142, Glu166, are evidenced in the diagram (b). Note the highly stabilized nature of the predicted lauruside-protease complex due to the multiple H-bonding possibilities given by the interactions of the compound hydroxyl moieties with the protein amino acids

the compounds extracted from bay laurel and from other Mediterranean plants. Nevertheless, before proposing laurusides as antiviral drugs or the inhalative applications of Laurus nobilis L. oil for ameliorating the health conditions of COVID-19 patients, the toxicity of the compounds and the allergenic potential of bay laurel essential oil should be carefully evaluated (Hensel et al. 2020). In this context, we suggest that chemical modifications of lauruside 5 could lead to structures endowed with high affinity for $\mathrm{M}^{\text {pro }}$ and, hopefully, with even better toxicity profiles, which could be effectively and safely employed in the anti-COVID-19 treatments.

\section{Conclusion}

We analysed the impact of COVID-19 in different Italian regions and found clues on the relationship between the severity of the disease and certain environmental factors, including scarcity of non-deciduous vegetation. The lowest impact of the pandemic was observed in the southern regions which have the highest rates of forest area per capita ( $\geq 0.34$ hectares/inhabitant) such as Basilicata, Calabria and Molise. This is interesting when compared to certain regions of northern Italy like Lombardy, Emilia Romagna and Veneto, which have less than 0.20 forest hectares/inhabitant and where the effects of COVID-19 were much more severe. We have, thus, suggested that a possible protective factor could be the presence of Mediterranean evergreen vegetation formed by both spontaneous and cultivated trees and shrubs. 
In our hypothesis, we speculate that during the mild winter of the Mediterranean regions, non-deciduous plants maintain, even though at a lower level, activities of air depuration and biogenic VOC emission able in some cases to bolster the human body's immunity and, thus could have contributed to the protection of southern populations from SARS-CoV-2. Nevertheless, mild climate, higher average sunlight exposure and the Mediterranean diet, which includes the consumption of foods containing polyphenols and natural compounds with potential antiviral activities, could have all contributed in the defence against the pandemic. As an example, we examined more than forty compounds discovered in bay laurel, a typical Mediterranean evergreen tree of common culinary use, and found that nine of them had a significantly high affinity for SARS-CoV-2 main protease $\mathrm{M}^{\text {pro }}$, one of the most important targets in the anti-COVID-19 therapeutic strategies. Among these laurel-derived ligands, lauruside 5 emerged from our study as the most promising candidate as a potential $\mathrm{M}^{\text {pro }}$ inhibitor. Moreover, despite its lower binding affinity for the protease when compared to lauruside 5, kaempferol, a natural compound isolated not only from Laurus nobilis L. but also from other Mediterranean plants like Quercus Ilex L. (Sebai et al. 2019), especially in glucosidated form (Karioti et al. 2010), could act as a potentially effective $\mathrm{M}^{\text {pro }}$ inhibitor. Remarkably, still showing an interesting predicted binding energy $(-7.4 \mathrm{kcal} / \mathrm{mol}$ for the top scoring pose), it is also endowed with an even more favourable predicted toxicity profile (Class V) than laurusides.

Acknowledgements We are grateful to Mr. Gergely Prikler and Mr. Gergely Takács (Mcule team, Hungary) for their kind support in molecular docking studies, and to Mrs. Melinda Gilhen-Baker (Ottawa, Canada) for useful discussion and editing the manuscript for English style and logical flow. This study was performed by the authors in smartworking mode (activated by Consiglio Nazionale delle Ricerche-CNR and University of Naples Federico II-UNINA during the COVID-19 crisis).We dedicate this study to all the health-care workers, and to all the people who suffered and still suffer around the world as a result of the COVID-19 pandemic.

\section{References}

Abed-Esfahani A, Amini H, Samadi N, Kar S, Hoodaji M, Shirvani M, Porsakhi K (2013a) The Evaluation of anticipated performance index of some plants species in east green belt of Isfahan. Tech J Eng Appl Sci 3(5):432-436

Abed-Esfahani A, Amini H, Samadi N, Kar S, Hoodaji M, Shirvani M, Porsakhi K (2013b) Assessment of air pollution tolerance index of higher plants suitable for green belt development in east of Esfahan city. Iran J Ornam Hortic 3(2):87-94

Alessi N, Wellstein C, Spada F, Zerbe S (2018) Phytocoenological approach to the ecology of Laurus nobilis L. Italy Rend Lincei Sci Fis Nat 29(2):343-354. https://doi.org/10.1007/s1221 0-018-0677-8
Anderson RM, May RM, McLean AR, Pattison J, Weiss RA, Fraser C, Ghani AC, Donnelly CA, Riley S, Ferguson NM, Leung GM, Lam TH, Hedley AJ (2004) Epidemiology, transmission dynamics and control of SARS: the 2002-2003 epidemic. Philos Trans R Soc Lond B Biol Sci 359(1447):1091-1105. https://doi.org/10.1098/ rstb.2004.1490

Bashir MF, Ma BJ, Bilal KB, Bashir MA, Farooq TH, Iqbal N, Bashir $M$ (2020) Correlation between environmental pollution indicators and COVID-19 pandemic: a brief study in Californian context. Environ Res 187:109652. https://doi.org/10.1016/j.envre s.2020.109652

Becker S, Soukup JM (1999) Exposure to urban air particulates alters the macrophage-mediated inflammatory response to respiratory viral infection. J Toxicol Environ Health, Part A 57(7):445-457. https://doi.org/10.1080/009841099157539

Berman HM, Battistuz T, Bhat TN, Bluhm WF, Bourne PE, Burkhardt K, Feng Z, Gilliland GL, Iype L, Jain S, Fagan P, Marvin J, Padilla D, Ravichandran V, Schneider B, Thanki N, Weissig H, Westbrook JD, Zardecki C (2002) The Protein Data Bank. Acta Crystallogr Sect D Biol Crystallogr 58(6):899-907. https://doi. org/10.1107/s0907444902003451

Blanusa T, Fantozzi F, Monaci F, Bargagli R (2015) Leaf trapping and retention of particles by holm oak and other common tree species in Mediterranean urban environments. Urban For Urban Green 14(4):1095-1101. https://doi.org/10.1016/j.ufug.2015.10.004

Cai Q-C, Lu J, Xu Q-F, Guo Q, Xu D-Z, Sun Q-W, Yang H, Zhao G-M, Jiang Q-W (2007) Influence of meteorological factors and air pollution on the outbreak of severe acute respiratory syndrome. Public Health 121(4):258-265. https://doi.org/10.1016/j. puhe.2006.09.023

Cena H, Chieppa M (2020) Coronavirus disease (COVID-19-SARS$\mathrm{CoV}-2)$ and nutrition: is infection in Italy suggesting a connection? Front Immunol. https://doi.org/10.3389/fimmu.2020.00944

Chakraborti S, Bheemireddy S, Srinivasan N (2020) Repurposing drugs against main protease of SARS-CoV-2: mechanism-based insights supported by available laboratory and clinical data. Mol Omics. https://doi.org/10.1039/d0mo00057d

Chen N, Sun G, Yuan X, Hou J, Wu Q, Soromou LW, Feng H (2014) Inhibition of lung inflammatory responses by bornyl acetate is correlated with regulation of myeloperoxidase activity. J Surg Res 186(1):436-445. https://doi.org/10.1016/j.jss.2013.09.003

Conticini E, Frediani B, Caro D (2020) Can atmospheric pollution be considered a co-factor in extremely high level of SARS-CoV-2 lethality in Northern Italy? Environ Pollut 261:114465. https:// doi.org/10.1016/j.envpol.2020.114465

Costanzo M, De Giglio MAR, Roviello GN (2020) SARS CoV-2: recent reports on antiviral therapies based on lopinavir/ritonavir, darunavir/umifenovir, hydroxychloroquine, remdesivir, favipiravir and other drugs for the treatment of the new coronavirus. Curr Med Chem. https://doi.org/10.2174/09298673276662004161 31117

da Silva JKR, Figueiredo PLB, Byler KG, Setzer WN (2020) Essential oils as antiviral agents, potential of essential oils to treat SARS-CoV-2 infection: an in-silico investigation. Int J Mol Sci 21(10):3426. https://doi.org/10.3390/ijms21103426

Dang X, Shan Z (2017) Dust pollution and control with leather waste. Environ Chem Lett 16(2):427-437. https://doi.org/10.1007/s1031 1-017-0683-6

D'Auria M, Racioppi R (2015) The effect of drying of the composition of volatile organic compounds in rosmarinus officinalis, laurus nobilis, salvia officinalis and thymus serpyllum. a HS-SPME-GCMS study. J Essent Oil-Bear Plants 18(5):1209-1223. https://doi. org/10.1080/0972060x.2014.895213

De Marino S, Borbone N, Zollo F, Ianaro A, Di Meglio P, Iorizzi M (2004) Megastigmane and phenolic components from Laurus nobilis $L$. leaves and their inhibitory effects on nitric oxide 
production. J Agric Food Chem 52(25):7525-7531. https://doi. org/10.1021/jf048782t

Distante C, Piscitelli P, Miani A (2020) Covid-19 outbreak progression in Italian regions: approaching the peak by the end of march in Northern Italy and first week of April in Southern Italy. Int J Environ Res Pub He 17(9):3025. https://doi. org/10.3390/ijerph17093025

Drwal MN, Banerjee P, Dunkel M, Wettig MR, Preissner R (2014) ProTox: a web server for the in silico prediction of rodent oral toxicity. Nucleic Acids Res 42(W1):W53-W58. https://doi. org/10.1093/nar/gku401

Duc Dat L, Viet Duc N, Thuy Luyen BT, Van Oanh H, Jang HJ, Huong TT, Ho Kim Y, Thao NP (2019) Megastigmane and abscisic acid glycosides from the leaves of Laurus nobilis L. Phytochem Lett 33:1-5. https://doi.org/10.1016/j.phyto 1.2019.06.011

Dutheil F, Navel V, Clinchamps M (2020) The indirect benefit on respiratory health from the world's effort to reduce transmission of SARS - CoV-2. Chest. https://doi.org/10.1016/j.chest.2020.03.062

Fares S, Sanesi G, Vacchiano G, Salbitano F, Marchetti M (2020) Urban forests at the time of COVID-19 protect us from fine dust. Forest@ - Rivista di Selvicoltura ed Ecologia Forestale 17(3):4851. https://doi.org/10.3832/efor3494-017

Fellet G, Pošćić F, Licen S, Marchiol L, Musetti R, Tolloi A, Barbieri P, Zerbi G (2016) PAHs accumulation on leaves of six evergreen urban shrubs: a field experiment. Atmos Pollut Res 7(5):915-924. https://doi.org/10.1016/j.apr.2016.05.007

Feng R, Zheng H-j (2019) Evidence for regional heterogeneous atmospheric particulate matter distribution in China: implications for air pollution control. Environ Chem Lett 17(4):1839-1847. https ://doi.org/10.1007/s10311-019-00890-0

Fidan H, Stefanova G, Kostova I, Stankov S, Damyanova S, Stoyanova A, Zheljazkov VD (2019) Chemical composition and antimicrobial Activity of Laurus nobilis L. Essent Oils Bulg Mol 24(4):804. https://doi.org/10.3390/molecules24040804

Fik-Jaskółka MA, Mkrtchyan AF, Saghyan AS, Palumbo R, Belter A, Hayriyan LA, Simonyan H, Roviello V, Roviello GN (2020a) Biological macromolecule binding and anticancer activity of synthetic alkyne-containing 1-phenylalanine derivatives. Amino Acids 52(5):755-769. https://doi.org/10.1007/s00726-020-02849-w

Fik-Jaskółka MA, Mkrtchyan AF, Saghyan AS, Palumbo R, Belter A, Hayriyan LA, Simonyan H, Roviello V, Roviello GN (2020b) Spectroscopic and SEM evidences for G4-DNA binding by a synthetic alkyne-containing amino acid with anticancer activity. Spectrochim Acta A Mol Biomol Spectrosc 229:117884. https:// doi.org/10.1016/j.saa.2019.117884

Frogoudaki AA (2020) Preparing for the tsunami or the way towards flattening the curve, the Greek perspective. Eur J Heart Fail. https ://doi.org/10.1002/ejhf.1872

Gratani L, Varone L (2013) Carbon sequestration and noise attenuation provided by hedges in Rome: the contribution of hedge traits in decreasing pollution levels. Atmos Pollut Res 4(3):315-322. https ://doi.org/10.5094/apr.2013.035

Grzędzicka E (2019) Is the existing urban greenery enough to cope with current concentrations of PM2.5, PM10 and $\mathrm{CO}_{2}$ ? Atmos Poll Res 10(1):219-233. https://doi.org/10.1016/j.apr.2018.08.002

Hashmi MA, Khan A, Hanif M, Farooq U, Perveen S (2015) Traditional uses, phytochemistry, and pharmacology of olea europaea (Olive). Evid-Based Complement Altern Med 2015:1-29. https ://doi.org/10.1155/2015/541591

Hensel A, Bauer R, Heinrich M, Spiegler V, Kayser O, Hempel G, Kraft K (2020) Challenges at the time of COVID-19: opportunities and innovations in antivirals from nature. Planta Med. https ://doi.org/10.1055/a-1177-4396

Hunter P (2020) The spread of the COVID-19 coronavirus. EMBO Rep. https://doi.org/10.15252/embr.202050334
Jiang Y, Wu X-J, Guan Y-J (2020) Effect of ambient air pollutants and meteorological variables on COVID-19 incidence. Inf Control Hosp Epidem 11:1-5. https://doi.org/10.1017/ice.2020.222

Jin Z, Du X, Xu Y, Deng Y, Liu M, Zhao Y, Zhang B, Li X, Zhang L, Peng C, Duan Y, Yu J, Wang L, Yang K, Liu F, Jiang R, Yang X, You T, Liu X, Yang X, Bai F, Liu H, Liu X, Guddat LW, Xu W, Xiao G, Qin C, Shi Z, Jiang H, Rao Z, Yang H (2020) Structure of $\mathrm{M}$ pro from SARS-CoV-2 and discovery of its inhibitors. Nature. https://doi.org/10.1038/s41586-020-2223-y

Juergens U (2014) Anti-inflammatory properties of the monoterpene 1.8-cineole: current evidence for co-medication in inflammatory airway diseases. Drug Res 64(12):638-646. https://doi. org/10.1055/s-0034-372609

Kahkha MRR, Amanloo S, Kaykhaii M (2013) Antiaflatoxigenic activity of Carum copticum essential oil. Environ Chem Lett 12(1):231-234. https://doi.org/10.1007/s10311-013-0439-x

Karioti A, Bilia AR, Skaltsa H (2010) Quercus ilex L.: A rich source of polyacylated flavonoid glucosides. Food Chem 123(1):131-142. https://doi.org/10.1016/j.foodchem.2010.04.020

Kaur M, Nagpal AK (2017) Evaluation of air pollution tolerance index and anticipated performance index of plants and their application in development of green space along the urban areas. Environ Science Poll Res 24(23):18881-18895. https://doi.org/10.1007/ s11356-017-9500-9

Kfoury M, Borgie M, Verdin A, Ledoux F, Courcot D, Auezova L, Fourmentin S (2016) Essential oil components decrease pulmonary and hepatic cells inflammation induced by air pollution particulate matter. Environ Chem Lett 14(3):345-351. https://doi. org/10.1007/s10311-016-0572-4

Kim T, Song B, Cho KS, Lee I-S (2020) therapeutic potential of volatile terpenes and terpenoids from forests for inflammatory diseases. Int J Mol Sci 21(6):2187. https://doi.org/10.3390/ijms2 1062187

Kiss R, Sandor M, Szalai FA (2012)http://Mcule.com: a public web service for drug discovery. J Cheminform. https://doi. org/10.1186/1758-2946-4-s1-p17

Klauke AL, Racz I, Pradier B, Markert A, Zimmer AM, Gertsch J, Zimmer A (2014) The cannabinoid CB2 receptor-selective phytocannabinoid beta-caryophyllene exerts analgesic effects in mouse models of inflammatory and neuropathic pain. Eur Neuropsychopharmacol 24(4):608-620. https://doi.org/10.1016/j.euron euro.2013.10.008

Lai C-C, Shih T-P, Ko W-C, Tang H-J, Hsueh P-R (2020) Severe acute respiratory syndrome coronavirus 2 (SARS-CoV-2) and coronavirus disease-2019 (COVID-19): The epidemic and the challenges. Int J Antimicrob Agents 55(3): 105924. https://doi.org/10.1016/j. ijantimicag.2020.105924

Lambert H, Mohan N, Lee T-C (2019) Ultrahigh binding affinity of a hydrocarbon guest inside cucurbit[7]uril enhanced by strong hostguest charge matching. Phys Chem Chem Phys 21(27):1452114529. https://doi.org/10.1039/c9cp01762c

Li Q (2009) Effect of forest bathing trips on human immune function. Environ Health Prevent Med 15(1):9-17. https://doi.org/10.1007/ s12199-008-0068-3

Li Q, Morimoto K, Kobayashi M, Inagaki H, Katsumata M, Hirata Y, Hirata K, Suzuki H, Li YJ, Wakayama Y, Kawada T, Park BJ, Ohira T, Matsui N, Kagawa T, Miyazaki Y, Krensky AM (2008) Visiting a forest, but not a city, increases human natural killer activity and expression of anti-cancer proteins. Int $\mathrm{J}$ Immunopathol Pharmacol 21(1):117-127. https://doi.org/10.1177/03946 3200802100113

Loizzo MR, Saab AM, Tundis R, Statti GA, Menichini F, Lampronti I, Gambari R, Cinatl J, Doerr HW (2008) Phytochemical analysis and in vitro antiviral activities of the essential oils of seven lebanon species. Chem Biodivers 5(3):461-470. https://doi. org/10.1002/cbdv.200890045 
Lu R, Zhao X, Li J, Niu P, Yang B, Wu H, Wang W, Song H, Huang B, Zhu N, Bi Y, Ma X, Zhan F, Wang L, Hu T, Zhou H, Hu Z, Zhou W, Zhao L, Chen J, Meng Y, Wang J, Lin Y, Yuan J, Xie Z, Ma J, Liu WJ, Wang D, Xu W, Holmes EC, Gao GF, Wu G, Chen W, Shi W, Tan W (2020) Genomic characterisation and epidemiology of 2019 novel coronavirus: implications for virus origins and receptor binding. Lancet 395(10224):565-574. https://doi.org/10.1016/ s0140-6736(20)30251-8

Mangum EM, Graham KK (2001) Lopinavir-Ritonavir: a new protease inhibitor. Pharmacotherapy 21(11):1352-1363. https://doi. org/10.1592/phco.21.17.1352.34419

Micol V, Caturla N, Perezfons L, Mas V, Perez L, Estepa A (2005) The olive leaf extract exhibits antiviral activity against viral haemorrhagic septicaemia rhabdovirus (VHSV). Antivir Res 66(2-3):129-136. https://doi.org/10.1016/j.antiviral.2005.02.005

Muhammad S, Long X, Salman M (2020) COVID-19 pandemic and environmental pollution: a blessing in disguise? Sci Total Environ 728:138820. https://doi.org/10.1016/j.scitotenv.2020.138820

Mukherjee A, Agrawal M (2017) World air particulate matter: sources, distribution and health effects. Environ Chem Lett 15(2):283-309. https://doi.org/10.1007/s10311-017-0611-9

Mukherjee A, Agrawal M (2018) Air pollutant levels are 12 times higher than guidelines in Varanasi, India. Sources Transfer Environ Chem Lett 16(3):1009-1016. https://doi.org/10.1007/s1031 1-018-0706-y

Nam S-Y, Chung C-k, Seo J-H, Rah S-Y, Kim H-M, Jeong H-J (2014) The therapeutic efficacy of $\alpha$-pinene in an experimental mouse model of allergic rhinitis. Int Immunopharmacol 23(1):273-282. https://doi.org/10.1016/j.intimp.2014.09.010

Nowak DJ, Hirabayashi S, Bodine A, Greenfield E (2014) Tree and forest effects on air quality and human health in the United States. Environ Pollut 193:119-129. https://doi.org/10.1016/j.envpo 1.2014 .05 .028

Nowak DJ, Hirabayashi S, Doyle M, McGovern M, Pasher J (2018) Air pollution removal by urban forests in Canada and its effect on air quality and human health. Urb For Urb Green 29:40-48. https:// doi.org/10.1016/j.ufug.2017.10.019

Odone A, Delmonte D, Scognamiglio T, Signorelli C (2020) COVID19 deaths in Lombardy, Italy: data in context. Lancet Public Health. https://doi.org/10.1016/s2468-2667(20)30099-2

Owen SM, Boissard C, Hewitt CN (2001) Volatile organic compounds (VOCs) emitted from 40 Mediterranean plant species. Atmos Environ 35(32):5393-5409. https://doi.org/10.1016/s1352 $-2310(01) 00302-8$

Özçelik B, Aslan M, Orhan I, Karaoglu T (2005) Antibacterial, antifungal, and antiviral activities of the lipophylic extracts of Pistacia vera. Microbiol Res 160(2):159-164. https://doi.org/10.1016/j. micres.2004.11.002

Panarese A, Shahini E (2020) Letter: Covid-19, and vitamin D. Aliment Pharmacol Ther 51(10):993-995. https://doi.org/10.1111/ apt. 15752

Park M, Thwaites RS, Openshaw PJM (2020) COVID-19: lessons from SARS and MERS. Eur J Immunol 50(3):308-311. https:// doi.org/10.1002/eji.202070035

Peytavin G, Yazdanpanah Y, Ader F, Mentré F, Néant N, Guedj J, Peiffer-Smadja N, Lê MP, Ader F, Yazdanpanah Y, Mentre F, Lescure F-X, Peiffer-Smadja N, Bouadma L, Poissy J, Timsit J-F, Lina B, Morfin-Sherpa F, Peytavin G, Burdet C, Laouenan C, Belhadi D, Dupont A, Basli B, Chair A, Laribi S, Level J, Schneider M, Tellier M-C, Dechanet A, Couffin-Cadiergues S, Delmas C, Esperou H, Fougerou C, Gelley A, Moinot L, Wittkop L, Cagnot C, Diallo A, Le Mestre S, Lebrasseur-Longuet D, Mercier N, Petrov-Sanchez V, Icard V, Leveau B, Guillon J, Taburet A-M, Noret M, d'Ortenzio E, Puechal O, Saillard J, Semaille C (2020) Rationale of a loading dose initiation for hydroxychloroquine treatment in COVID-19 infection in the DisCoVeRy trial. J Antimicrob Chemother. https://doi.org/10.1093/jac/dkaa191

Pignatti E, Pignatti S, D’Angeli D, De Nicola C, Maffei L, Testi A, Tinelli A (2015) The Laurisilva as a cultural heritage: proposal for the protection of the relict of laurel forest near Ponte Renaro. Rend Lincei 26(S3):643-649. https://doi.org/10.1007/s1221 0-015-0389-2

Potemkin V, Potemkin A, Grishina M (2019) Internet resources for drug discovery and design. Curr Top Med Chem 18(22):19551975. https://doi.org/10.2174/1568026619666181129142127

Rarey M, Steinegger R, Nittinger E, Meyder A, Flachsenberg F, Fährrolfes R, Diedrich K, Schöning-Stierand K (2020) Proteinsplus: interactive analysis of protein-ligand binding interfaces. Nucleic Acids Res. https://doi.org/10.1093/nar/gkaa235

Riabov PA, Micić D, Božović RB, Jovanović DV, Tomić A, Šovljanski O, Filip S, Tosti T, Ostojić S, Blagojević S, Đurović S (2020) The chemical, biological and thermal characteristics and gastronomical perspectives of Laurus nobilis essential oil from different geographical origin. Ind Crop Prod 151:112498. https://doi. org/10.1016/j.indcrop.2020.112498

Rivoal A, Fernandez C, Lavoir AV, Olivier R, Lecareux C, Greff S, Roche P, Vila B (2010) Environmental control of terpene emissions from Cistus monspeliensis L. in natural Mediterranean shrublands. Chemosphere 78(8):942-949. https://doi. org/10.1016/j.chemosphere.2009.12.047

Saglietto A, D'Ascenzo F, Zoccai GB, De Ferrari GM (2020) COVID19 in Europe: the Italian lesson. Lancet 395(10230):1110-1111. https://doi.org/10.1016/S0140-6736(20)30690-5

Sanna C, Rigano D, Cortis P, Corona A, Ballero M, Parolin C, Del Vecchio C, Chianese G, Saccon E, Formisano C, Tramontano E, Esposito F (2018) Onopordum illyricum L., a Mediterranean plant, as a source of anti HIV-1 compounds. Plant Biosyst Int J Deal Aspects Plant Biol 152(6):1274-1281. https://doi. org/10.1080/11263504.2018.1439118

Sebai H, Rtibi K, Selmi S, Jridi M, Balti R, Marzouki L (2019) Modulating and opposite actions of two aqueous extracts prepared from Cinnamomum cassia L. bark and Quercus ilex L. on the gastrointestinal tract in rats. RSC Adv 9(38):21695-21706. https://doi. org/10.1039/c9ra02429h

Setti L, Passarini F, De Gennaro G, Barbieri P, Perrone MG, Borelli M, Palmisani J, Di Gilio A, Torboli V, Fontana F, Clemente L, Pallavicini A, Ruscio M, Piscitelli P, Miani A (2020) SARSCov-2RNA found on particulate matter of Bergamo in Northern Italy: first evidence. Environ Res. https://doi.org/10.1016/j.envre s.2020.109754

Sgrigna G, Sæbø A, Gawronski S, Popek R, Calfapietra C (2015) Particulate Matter deposition on Quercus ilex leaves in an industrial city of central Italy. Environ Pollut 197:187-194. https://doi. org/10.1016/j.envpol.2014.11.030

Sharma VK, Jinadatha C, Lichtfouse E (2020) Environmental chemistry is most relevant to study coronavirus pandemics. Environ Chem Lett 18(4):993-996. https://doi.org/10.1007/s10311-02001017-6

Signorelli C, Scognamiglio T, Odone A (2020) COVID-19 in Italy: impact of containment measures and prevalence estimates of infection in the general population. Acta Biomed 91((3-S)):175179. https://doi.org/10.23750/abm.v91i3-S.9511

Sinonquel P, Roelandt P, Demedts I, van Gerven L, Vandenbriele C, Wilmer A, Van Wijngaerden E, Bisschops R (2020) COVID19 and gastrointestinal endoscopy: what should be taken into account? Digest Endosc. https://doi.org/10.1111/den.13706

Snene A, El Mokni R, Jmii H, Jlassi I, Jaïdane H, Falconieri D, Piras A, Dhaouadi H, Porcedda S, Hammami S (2017) In vitro antimicrobial, antioxidant and antiviral activities of the essential oil and various extracts of wild (Daucus virgatus (Poir.) Maire) from 
Tunisia. Ind Crop Prod 109:109-115. https://doi.org/10.1016/j. indcrop.2017.08.015

Sun Q, Xu Q, Li X, Wang S, Wang C, Huang F, Gao Q, Wu L, Tao L, Guo J, Wang W, Guo X (2016) Fine particulate air pollution and hospital emergency room visits for respiratory disease in urban areas in Beijing, China, in 2013. PLoS ONE 11(4):e0153099. https://doi.org/10.1371/journal.pone.0153099

Trott O, Olson AJ (2009) AutoDock Vina: improving the speed and accuracy of docking with a new scoring function, efficient optimization, and multithreading. J Comput Chem 31(2):455-461. https ://doi.org/10.1002/jcc.21334

Umesh KD, Selvaraj C, Singh SK, Dubey VK (2020) Identification of new anti-nCoV drug chemical compounds from Indian spices exploiting SARS-CoV-2 main protease as target. J Biomol Struct Dyn. https://doi.org/10.1080/07391102.2020.1763202

Wang L, Li M, Yu S, Chen X, Li Z, Zhang Y, Jiang L, Xia Y, Li J, Liu W, Li P, Lichtfouse E, Rosenfeld D, Seinfeld JH (2020) Unexpected rise of ozone in urban and rural areas, and sulfur dioxide in rural areas during the coronavirus city lockdown in Hangzhou, China: implications for air quality. Environ Chem Lett. https://doi. org/10.1007/s10311-020-01028-3

Worth H, Dethlefsen U (2012) Patients with asthma benefit from concomitant therapy with cineole: a placebo-controlled. Double-Blind Trial J Asthma 49(8):849-853. https://doi.org/10.3109/02770 903.2012.717657

Wu D, Wu T, Liu Q, Yang Z (2020) The SARS-CoV-2 outbreak: what we know. Int J Infect Dis 94:44-48. https://doi.org/10.1016/j. ijid.2020.03.004

Xie J, Teng J, Fan Y, Xie R, Shen A (2019) The short-term effects of air pollutants on hospitalizations for respiratory disease in Hefei. China Int J Biometeorol 63(3):315-326. https://doi.org/10.1007/ s00484-018-01665-y
Xu H, Yan C, Fu Q, Xiao K, Yu Y, Han D, Wang W, Cheng J (2020) Possible environmental effects on the spread of COVID-19 in China. Sci Total Environ 731:139211. https://doi.org/10.1016/j. scitotenv.2020.139211

Yousef OM, El Raaey M, El Shaaraw TH, El Sanousi AA, Shalaby MA (2014a) Primary screening of antiviral potential of quercus ilex (wood) extract against BVDV: a pestivirus model of hepatitis C virus. Int J Virol 10(2):112-120. https://doi.org/10.3923/ ijv.2014.112.120

Yousef O, El-Raey M, El-Sanousi AA, Shalaby MA (2014b) In vitro primary evaluation of antiviral activity of crude extract of quercus ilex L. against amantadine resistant orthomyxo virus. Int J Virol 10(1):17-27. https://doi.org/10.3923/ijv.2014.17.27

Yu S (2018) Fog geoengineering to abate local ozone pollution at ground level by enhancing air moisture. Environ Chem Lett 17(1):565-580. https://doi.org/10.1007/s10311-018-0809-5

Zhang L, Lin D, Sun X, Curth U, Drosten C, Sauerhering L, Becker S, Rox K, Hilgenfeld R (2020) Crystal structure of SARS$\mathrm{CoV}-2$ main protease provides a basis for design of improved $\alpha$-ketoamide inhibitors. Science. https://doi.org/10.1126/scien ce.abb3405

Zhu Y, Xie J, Huang F, Cao L (2020) Association between short-term exposure to air pollution and COVID-19 infection: evidence from China. Sci Total Environ 727:138704. https://doi.org/10.1016/j. scitotenv.2020.138704

Publisher's Note Springer Nature remains neutral with regard to jurisdictional claims in published maps and institutional affiliations. 